\title{
What Is the Antibody Response and Role in Conferring Natural Immunity After SARS-CoV-2 Infection? Rapid, Living Practice Points From the American College of Physicians (Version 2)
}

\author{
Amir Qaseem, MD, PhD, MHA; Jennifer Yost, RN, PhD; Itziar Etxeandia-Ikobaltzeta, PharmD, PhD; Mary Ann Forciea, MD; \\ George M. Abraham, MD, MPH; Matthew C. Miller, MD; Adam J. Obley, MD; and Linda L. Humphrey, MD, MPH; for the \\ Scientific Medical Policy Committee of the American College of Physicians*
}

Description: The Scientific Medical Policy Committee (SMPC) of the American College of Physicians (ACP) developed these living, rapid practice points to summarize the current best available evidence on the antibody response to SARS-CoV-2 infection and protection against reinfection with SARS-CoV-2. This is version 2 of the ACP practice points, which serves to update version 1, published on 16 March 2021. These practice points do not evaluate vaccine-acquired immunity or cellular immunity.

Methods: The SMPC developed this version of the living, rapid practice points based on an updated living, rapid, systematic review conducted by the Portland VA Research Foundation and funded by the Agency for Healthcare Research and Quality.

Practice Point 1: Do not use SARS-CoV-2 antibody tests for the diagnosis of SARS-CoV-2 infection.
Practice Point 2: Do not use SARS-CoV-2 antibody tests to predict the degree or duration of natural immunity conferred by antibodies against reinfection, including natural immunity against different variants.

Retirement From Living Status: Although natural immunity remains a topic of scientific interest, this topic is being retired from living status given the availability of effective vaccines for SARS-CoV-2 and widespread recommendations for and prevalence of their use. Currently, vaccination is the best clinical recommendation for preventing infection, reinfection, and serious illness from SARS-CoV-2 and its variants.

Ann Intern Med. doi:10.7326/M21-3272

Annals.org For author, article, and disclosure information, see end of text. This article was published at Annals.org on 25 January 2022.
T he Scientific Medical Policy Committee (SMPC) of the American College of Physicians (ACP) has been maintaining these living, rapid practice points to summarize the current best available evidence on the antibody response to SARS-CoV-2 infection and protection against reinfection with SARS-CoV-2 (Table 1). This is version 2 of the ACP practice points, which serves to update version 1, published on 16 March $2021(3,4)$. It is based on a focused update of a living, rapid, systematic review conducted by the Portland VA Research Foundation and funded by the Agency for Healthcare Research and Quality $(5,6)$. The SMPC developed these practice points according to ACP's practice points development process, details of which can be found in ACP's methods paper (7).

The intended audience for these practice points includes clinicians, patients, the public, and public health officials. The population includes adults who have been previously infected with SARS-CoV-2.

This version was approved by the ACP Executive Committee of the Board of Regents on behalf of the Board of Regents on 9 August 2021 and was submitted to Annals of Internal Medicine on 6 August 2021.

Although vaccine-acquired immunity and cellular immunity are important areas of research, this article does not evaluate them.

\section{Key Questions Addressed in the Living ANd Rapid Systematic Review}

Key Question 1 (not updated): What are the prevalence, level, and duration of detectable anti-SARS-CoV-2 antibodies among patients infected with or recovered from reverse transcriptase polymerase chain reaction (RT-PCR)-diagnosed SARS-CoV-2 infection?

\section{See also:}

Editorial comment

Related article

\footnotetext{
* This paper, written by Amir Qaseem, MD, PhD, MHA; Jennifer Yost, RN, PhD; Itziar Etxeandia-lkobaltzeta, PharmD, PhD; Mary Ann Forciea, MD; George M. Abraham, MD, MPH; Matthew C. Miller, MD; Adam J. Obley, MD; and Linda L. Humphrey, MD, MPH, was developed for the Scientific Medical Policy Committee of the American College of Physicians. Individuals who served on the Scientific Medical Policy Committee from initiation of the project until its approval were Linda L. Humphrey, MD, MPH† (Chair); Adam J. Obley, MD† (Vice Chair); Robert M. Centor, MD (Immediate Past Vice Chair); Elie A. Akl, MD, MPH, PhD†;

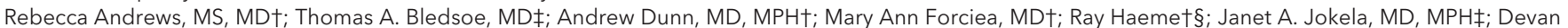
L. Kansagara, MD, MCR†; Maura Marcucci, MD, MScł; Matthew C. Miller, MDt; and CDR Mark P. Tschanz, DO†. Kate Carroll, MPH, and Shannon Merillat, MPH, MLIS, were nonauthor contributors from ACP staff. Approved by the ACP Executive Committee of the Board of Regents on behalf of the Board of Regents on 9 August 2021.

† Author.

‡Nonauthor contributor.

$\S$ Nonphysician public representative.

Update Alerts: The literature update end date is 22 September 2021. No further updates for this topic are planned at this time.
} 


\section{4able 1. Practice Points}

Evidence is emerging about the antibody response after initial infection with SARS-CoV-2, as well as protection against future reinfection with SARSCoV-2. These practice points do not evaluate vaccine-acquired immunity or cellular immunity. Vaccination is currently the best clinical recommendation for preventing SARS-CoV-2 infection or reinfection (1, 2). The following practice points are based on the current best available evidence. Practice Point 1: Do not use SARS-CoV-2 antibody tests for the diagnosis of SARS-CoV-2 infection.

Practice Point 2: Do not use SARS-CoV-2 antibody tests to predict the degree or duration of natural immunity conferred by antibodies against reinfection, including natural immunity against different variants.

What has changed in the practice points since the last version?

- No changes to Practice Point 1.

- Retired Practice Point 2 from version 1, which stated, "Antibody tests can be useful for the purpose of estimating community prevalence of SARS-CoV-2 infection." This statement now has limited relevance in the United States because of widespread vaccine-associated antibodies and limitations in antibody testing to differentiate whether antibodies developed due to past infection with SARS-CoV-2 or vaccination.

- Modified the text of former Practice Point 3 (now Practice Point 2) with a more clear, actionable statement. This practice point previously stated, "Current evidence is uncertain to predict presence, level, or durability of natural immunity conferred by SARS-CoV-2 antibodies against reinfection (after SARS-CoV-2 infection)."

Key Question 1a (not updated): Do the levels and durability of detectable antibodies vary by patient characteristics (for example, age, sex, race/ethnicity, and comorbidities), COVID-19 severity (severity of the initial infection), presence of symptoms, time from symptom onset, or the characteristics of the immunoassay (sensitivity, specificity)?

Key Question 2 (updated): What is the risk for reinfection with SARS-CoV-2 among adults with prior SARS-CoV-2 infection?

Key Question 2a (updated): Does the risk for reinfection vary by patient characteristics (for example, age, sex, race/ethnicity, and comorbidities), severity of the initial infection, initial antibody levels, or SARS-CoV-2 variants?

Key Question 2b (updated): Is there a threshold level of detectable anti-SARS-CoV-2 antibodies necessary to confer natural immunity, and if so, does this threshold vary by patient characteristics (for example, age, sex, race/ethnicity, and comorbidities)?

Key Question 3 (updated): What is the duration of protection against reinfection among adults with prior SARS-CoV-2 infection?

Key Question 3a (updated): Does the duration of protection vary by patient characteristics (for example, age, sex, race/ethnicity, and comorbidities), severity of initial infection, initial antibody levels, SARS-CoV-2 variants, or case identification method (for example, surveillance, symptomatic testing only)?

Key Question 4 (not updated): What are the unintended consequences of antibody testing after SARS-CoV-2 infection?

\section{Key Questions: Rationale For a Focused} Update to the Living and Rapid Systematic

\section{REVIEW}

Updates to key questions in the living, rapid, systematic review are prioritized on the basis of identification of new evidence from literature surveillance that will likely substantially modify the conclusions or the certainty of evidence. Based on literature surveillance, the Portland VA Research Foundation and the SMPC determined that there was a signal to perform a focused update of key questions 2, 2a, 2b, 3, and 3a (large population-based studies that included uninfected comparison groups were published) and that the evidence for key questions 1, 1a, and 4 had not matured enough to evaluate the long-term persistence of antibodies, which would substantially modify the conclusions or certainty of evidence in the previous version. Consistent with methods for living systematic reviews and our living, rapid practice points (7), the inclusion criteria were modified to include large longitudinal studies with control groups to evaluate the risk for reinfection, and key questions were modified for clarity (Appendix Table, available at Annals.org).

\section{Overview of New Evidence}

The evidence update $(5,6)$ identified 18 new studies (8-25) informing key questions 2, 2a, and 3, for which there were previously no studies that met the inclusion criteria in version 1 (3). These studies were initiated before the emergence of the Delta and Omicron variants and before the U.S. Food and Drug Administration's emergency use authorization of vaccines late in 2020 (5, 6). The new studies compared the risk for symptomatic reinfection (as a primary outcome) among adults with a recent SARS-CoV-2 infection with the risk for infection among adults without a recent infection, with "recent" defined as within 7 months of initial SARS-CoV-2 infection. These studies were designed to evaluate risk for symptomatic reinfection, with risk for asymptomatic reinfection as a secondary outcome. The new studies showed that patients with a recent SARS-CoV-2 infection have a substantially reduced risk for symptomatic reinfection $(88 \%$ in the general population and $87 \%$ in health care workers) compared with those without a recent infection (key question 2) over follow-up of 4 to 13 months. There is also protection for asymptomatic reinfections, but the evidence is unclear about whether the degree of protection for asymptomatic reinfections is as high as it is for symptomatic reinfections. No evidence was identified on threshold levels of antibodies needed to confer protection from reinfection or the contribution of the antibody response to this protection (key question $2 \mathrm{~b}$ ). The systematic review update did not identify evidence from included studies on whether risk for reinfection varied by patient comorbidities (including immunosuppression) or by viral variants other than the Alpha variant (including the Delta and Omicron variants) (key question 2a), or whether the variation in the duration of protection varies by patient or clinical characteristics (key question 3a).

\section{Updated Practice Points and Rationales (VERSION 2)}

Evidence continues to emerge about the antibody response to SARS-CoV-2 infection and protection against 
Figure. Evidence description.

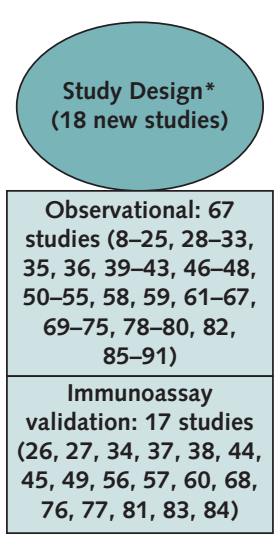

September 2021. PCR = polymerase chain reaction

* Observational studies include studies estimating seroprevalence among a given population that includes a small subpopulation known to have SARSCoV-2 infection; cross-sectional or cohort studies characterizing the antibody response among adults with SARS-CoV-2 infection; and large, populationbased observational (cohort, case-control) studies comparing risk for reinfection in adults with and without recent SARS-CoV-2 infection (3,5,6). Immunoassay validation studies include those validating the diagnostic performance of 1 or more immunoassays (3).

future reinfection. The following practice points are based on the current best available evidence. The Figure, Table 2, and the accompanying systematic review $(5,6)$ summarize changes in the findings. Table 3 presents clinical considerations, and Table 4 identifies evidence gaps.

We have retired Practice Point 2 from version 1, which stated, "Antibody tests can be useful for the purpose of estimating community prevalence of SARS-CoV-2 infection." The relevance of this statement is now limited given the increase in vaccinations in the United States and because antibody tests cannot differentiate antibodies that develop due to past SARS-CoV-2 infection from those that develop due to vaccination.

Practice Point 1: Do not use SARS-CoV-2 antibody tests for the diagnosis of SARS-CoV-2 infection

\section{Reaffirmed Rationale}

Studies included in the version 1 systematic review evaluated the prevalence, levels, and duration of different types of antibodies after symptom onset or confirmation of SARS-CoV-2 infection with a positive RT-PCR result (3). These studies showed that most patients develop detectable antibodies after SARSCoV-2 infection; however, the timing of when different antibodies peak and how long they remain detectable may vary (low to moderate certainty). Furthermore, the antibody response may vary by age, sex, race/ethnicity, and the severity of the initial infection (low certainty), and the evidence is very uncertain (insufficient) as to whether the response varies by comorbidities or type of immunoassay. In addition, the diagnostic test characteristics (for example, sensitivity, specificity, and accuracy) vary substantially across the antibody tests used in the included studies (3-6), contributing to differing risks for false-negative and false-positive results $(94,95)$. For these reasons, based on the studies included in version 1, antibody tests should not be used for the diagnosis of SARS-CoV-2 infection. 


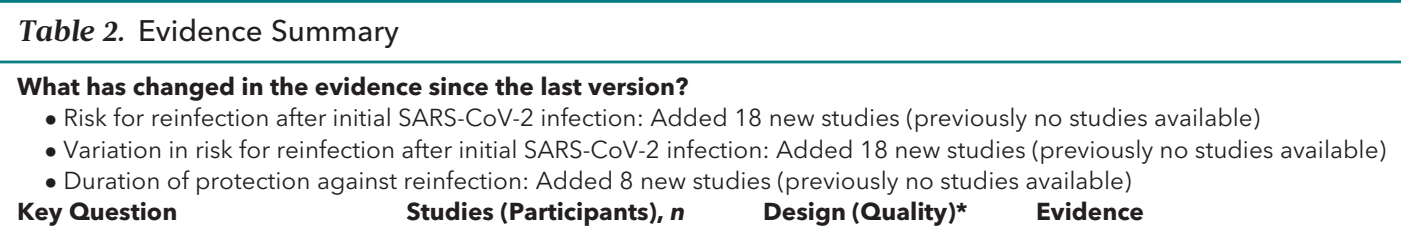

\section{Evidence}

$\begin{aligned} & \text { Prevalence of SARS-CoV-2 antibodies based on timing since symptom onset or con } \\ & \text { Not updated; based on search through } \mathbf{1 5} \text { December } \mathbf{2 0 2 0}\end{aligned}$
$\begin{array}{lll}21(6073) & 6 \text { OBS (good) } \\ \text { IgM } & 8 \text { OBS (poor) } \\ & 24(9136) & 7 \text { OBS (unclear) } \\ \operatorname{lgG} & 6 \text { OBS (good) } \\ & & 9 \text { OBS (poor) } \\ & 5(747) & 9 \text { OBS (unclear) } \\ \lg A & & 1 \text { OBS (good) } \\ & 8(979) & 2 \text { OBS (poor) } \\ \text { Neutralizing antibodies } & 2 \text { OBS (unclear) } \\ & & 3 \text { OBS (good) } \\ & & 1 \text { OBS (poor) } \\ & 4 \text { OBS (unclear) }\end{array}$

$>50 \%$ of patients probably develop an IgM antibody response $(36,39,41-43,47,48$, $50,53,58,59,63,66,69,71,72,86-90)$

$>90 \%$ of patients probably develop an lgG antibody response $(30,36,39,41,42,47$, $48,50,53,58,59,62,63,66,67,69,72$, $73,79,86-90)$

$>50 \%$ of patients may develop an $\operatorname{lgA}$ antibody response $(30,33,48,65,66)$

$>90 \%$ of patients may develop neutralizing antibodies $(35,39,48,50,51,73,79,82)$
Certainty of Evidence $†$

Moderate

Moderate

Low

Low

Antibodies probably peak at approximately 10 days after symptom onset or RT-PCR diagnosis and remain detectable for $\geq 115$ days $(28,32,33,35-37,42,43,45,46,52$, $53,58,63,66,69,72,82,85,87,88,90)$

Antibodies probably peak at approximately 25 days after symptom onset or RT-PCR diagnosis and remain detectable for $\geq 120$ days $(28,31,32,36,41-43,46,48,49,52-54,58$, $59,63,66,67,69,72,78,85,87,88,90)$

Antibodies may peak at approximately 16 to 20 days after symptom onset or RT-PCR diagnosis and may remain detectable for $\geq 140$ days $(33,41,46,49,65,66)$

Antibodies may peak at approximately 31 days after symptom onset or RT-PCR diagnosis and may remain detectable for $\geq 152$ days $(35,39,46,50,51,66,73,80)$

\begin{tabular}{|c|c|c|c|c|}
\hline Age & $12(9149)$ & $\begin{array}{l}6 \text { OBS (good) } \\
5 \text { OBS (unclear) } \\
1 \text { IV (unclear) }\end{array}$ & $\begin{array}{l}\text { Older age may be associated with higher } \\
\text { antibody levels }(31,32,39,41,43,51,53 \\
62,67,68,70,75)\end{array}$ & Low \\
\hline Sex & $12(7577)$ & $\begin{array}{l}8 \text { OBS (good) } \\
3 \text { OBS (unclear) } \\
1 \text { IV (unclear) }\end{array}$ & $\begin{array}{l}\text { The antibody response to SARS-CoV-2 infec- } \\
\text { tion may not vary by sex }(31,39,41,43 \text {, } \\
51,62,67,68,70,74,75,82)\end{array}$ & Low \\
\hline Race/ethnicity & $2(2724)$ & 2 OBS (good) & $\begin{array}{l}\text { Non-White race may be associated with higher } \\
\text { antibody prevalence and levels }(62,70)\end{array}$ & Low \\
\hline Comorbidities & $13(7477)$ & $\begin{array}{l}6 \text { OBS (good) } \\
6 \text { OBS (unclear) } \\
1 \text { IV (unclear) }\end{array}$ & $\begin{array}{l}\text { Very uncertain about whether the antibody } \\
\text { response to SARS-CoV-2 infection varies } \\
\text { with comorbidities }(31,32,38,39,41,43 \\
59,62,67,70,71,79,82)\end{array}$ & Insufficient \\
\hline Severity of initial infection & $29(8534)$ & $\begin{array}{l}6 \text { OBS (good) } \\
10 \text { OBS (poor) } \\
8 \text { OBS (unclear) } \\
5 \text { IV (unclear) }\end{array}$ & $\begin{array}{l}\text { More severe COVID-19 may be associated } \\
\text { with a more robust antibody response in } \\
\text { terms of antibody levels }(30-33,35,36, \\
\begin{array}{l}41-43,52,53,57-59,63,66,68,71,72 \\
75-78,83,85,87-89,91)\end{array}\end{array}$ & Low \\
\hline Presence of symptoms & $9(4793)$ & $\begin{array}{l}5 \text { OBS (good) } \\
1 \text { OBS (unclear) } \\
3 \text { IV (unclear) }\end{array}$ & $\begin{array}{c}\text { The presence of symptoms may be associ- } \\
\text { ated with higher antibody prevalence and } \\
\text { levels }(32,39,41,44,60,62,70,75,83)\end{array}$ & Low \\
\hline Immunoassays & $10(1996)$ & $\begin{array}{l}2 \text { OBS (good) } \\
1 \text { OBS (poor) } \\
1 \text { OBS (unclear) } \\
6 \text { IV (unclear) }\end{array}$ & $\begin{array}{l}\text { Very uncertain about whether the presence } \\
\text { of detectable antibodies varies on the ba- } \\
\text { sis of different immunoassays }(26,27,37 \text {, } \\
39,41,50,76-78,83)\end{array}$ & Insufficient \\
\hline
\end{tabular}




\begin{tabular}{|c|c|c|}
\hline \multicolumn{3}{|c|}{ Table 2-Continued } \\
\hline Key Question & Studies (Participants), $n$ & Design (Qualit) \\
\hline \multicolumn{3}{|c|}{$\begin{array}{l}\text { Risk for reinfection after initial SARS-CoV-2 infection (key question 2) } \\
\text { New studies; updated through } 22 \text { September } 2021\end{array}$} \\
\hline Risk for reinfection & $18(12968006)$ & $\begin{array}{l}12 \text { OBS (good) } \\
5 \text { OBS (fair) } \\
1 \text { OBS (poor) }\end{array}$ \\
\hline
\end{tabular}

Variation in risk for reinfection after initial SARS-CoV-2 infection (key question 2a) New studies; updated through 22 September 2021

5 (529 105)

5 OBS (good)

Sex

$18(12968006)$

Race/ethnicity

$1(4411)$

NA

Comorbidities

Initial antibody levels

$11(3241686)$

$10(12345502)$

Severity of initial infection

$3(27772)$

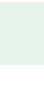

\author{
5 OBS (fair) \\ OBS (por)
}

(a)
Evidence

Recent SARS-CoV-2 infection in adults reduces risk for symptomatic reinfection by $84 \%$ to $90 \%$ compared with adults without a recent infection (8-25)

Note: Recent infection protects against asymptomatic reinfection; however, it is unclear whether the strength of protection from initial infection is as strong for asymptomatic reinfection as it is for symptomatic reinfection $\neq(8-11,13,18-25)$
Certainty of

Evidence $\dagger$

High

Threshold level of antibodies to confer natural immunity (key question 2b) Updated through 22 September 2021

NA NA

NA

No evidence

NA

Duration of protection against reinfection (key question 3 )

New studies; updated through 22 September 2021

Duration of protection $\quad 8(80206) \quad 5$ OBS (good)

2 OBS (fair)

1 OBS (poor)

Risk for reinfection may not vary by age (12, $15,17-19)$

Risk for reinfection does not vary by sex High (8-25)

Very uncertain about whether risk for reinfec- Insufficient tion varies by race/ethnicity (10)

No evidence

Very uncertain about how initial antibody lev- Insufficient els affect risk for reinfection (8-11, 13, 14, 16-20)

Mild or asymptomatic initial infections may be associated with higher risk for reinfection $(8,11,13,14,16,19,20,22,24,25)$

The Alpha variant may not affect protection against reinfection $(12,13,18)$

Low

ow

Low

Low 


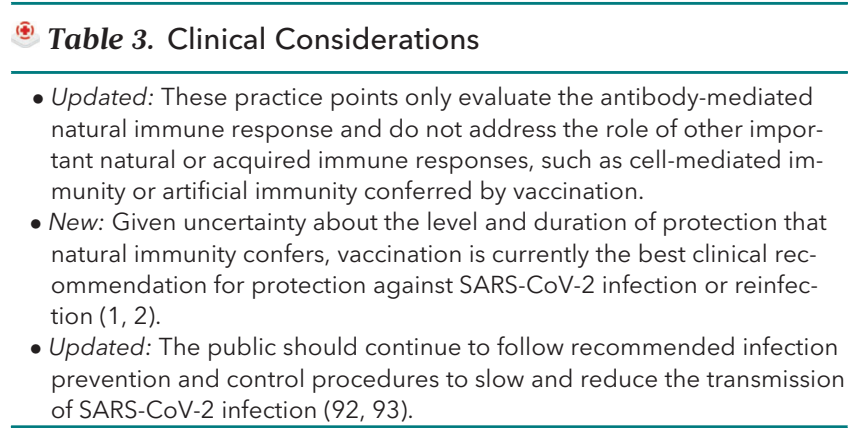

Practice Point 2: Do not use SARS-CoV-2 antibody tests to predict the degree or duration of natural immunity conferred by antibodies against reinfection, including natural immunity against different variants

\section{Updated Rationale}

Because measuring antibodies is an approach for evaluating the immune response, questions arise about the role of antibody testing in assessing natural immunity and protection from reinfection after SARS-CoV-2 infection. Although new evidence (18 new studies) has emerged addressing the risk for reinfection among adults with recent SARS-CoV-2 infection, several important evidence gaps remain in the new body of evidence that limit the clinical role of antibody testing (Table 4).

Low- to moderate-certainty evidence showed that patients with asymptomatic and symptomatic initial infections develop detectable antibodies (3), and high-certainty evidence from new studies showed that recent initial SARS-CoV-2 infection reduced the risk for symptomatic reinfection by $84 \%$ to $90 \%$ in adults over follow-up ranging from 4 to 13 months. This degree of protection may be similar across age groups (low certainty), with the Alpha variant (low certainty), in persons in the general

\section{? Table 4. Evidence Gaps}

- Studies are needed to understand why some patients with PCRconfirmed SARS-CoV-2 infection do not develop antibodies.

- New: Research is needed to determine the threshold levels of detectable SARS-CoV-2 antibodies that are necessary to provide continued protection against reinfection (antibodies from prior infection or vaccination) and to identify the most valid and reliable tests to determine these levels.

- Updated: Research is needed to understand the associations between antibody response and patient characteristics (age, sex, race/ethnicity, comorbidities, immunocompromised status, presence of symptoms, and severity of initial infection).

- Updated: Research is needed to determine how long protection from reinfection is conferred by antibodies and whether this varies by clinical and patient characteristics.

- New: The included studies were not entirely representative of patients who may be disproportionately affected by COVID-19. Research is needed to determine whether there are differences in protection against reinfection based on patient characteristics (age, race/ethnicity, comorbidities, and immunocompromised status).

- New: Research is needed to determine whether there are differences in protection against reinfection based on initial antibody levels, severity of initial infection, and SARS-CoV-2 variants.

$\mathrm{PCR}=$ polymerase chain reaction . population and health care workers, and does not vary according to sex (high certainty). However, these studies do not establish that antibodies are primarily responsible for the observed natural immunity because none of the new studies examined the relationship between antibody levels and degree of natural immunity, including threshold levels of detectable SARS-CoV-2 antibodies necessary to confer natural immunity. Furthermore, the included studies were conducted before the Delta and Omicron variants became the dominant circulating strains. However, the systematic review identified 3 studies that were not yet fully reported (96) or were longitudinal uncontrolled studies $(97,98)$ and thus did not meet the inclusion criteria; these studies suggest that recent SARS-CoV-2 infection reduced risk for reinfection in adults after the Delta variant became the dominant strain.

It is important to note that none of the new included studies reported on the variation in risk for reinfection in patients who are immunocompromised or have other comorbidities, and evidence is very uncertain (insufficient) about other factors that may modify risk for reinfection, including initial antibody levels and race/ethnicity. Evidence is also conflicting about risk for reinfection in patients who had an asymptomatic initial infection $(5,6)$; studies show that risk for reinfection may be higher for patients who had a mild or asymptomatic initial infection compared with those who had a symptomatic initial infection (low certainty). Although evidence suggests a high degree of protection $(>80 \%)$ against symptomatic SARS-CoV-2 reinfection in the short term (high certainty for up to 7 months and low certainty for 7 to 10 months), the duration of protection beyond 10 months is very uncertain (insufficient), and follow-up in the included studies is constrained by time elapsed since the beginning of the pandemic. Finally, none of the included studies reported on how the duration of protection might vary by such factors as variant strains, initial antibody levels, and patient characteristics.

Despite evidence that patients develop detectable antibodies (3) and have reduced risk for reinfection after initial SARS-CoV-2 infection, knowledge about the direct association of the antibody response and the degree of natural immunity to SARS-CoV-2 is still limited. In light of these evidence gaps, and considering previously reported insufficient (very uncertain) evidence (3) about the unintended consequences of antibody testing, we advise against antibody testing to evaluate for natural immunity. Patients with current or previous SARS-CoV-2 infection should continue to follow recommended infection prevention and control procedures to slow and reduce transmission of the virus $(92,93,99)$.

\section{Retirement From Living Status}

The SMPC is retiring the ACP living, rapid practice points on the antibody response to SARS-CoV-2 infection and protection against reinfection with SARS-CoV-2 from living status (7), given the widespread availability and use of effective vaccines against SARS-CoV-2 infection in the United States. Vaccination is currently the best clinical recommendation for prevention of SARS-CoV-2 infection 
and reinfection, including from currently circulating viral variants $(1,2)$.

From American College of Physicians, Philadelphia, Pennsylvania (A.Q., I.E.); American College of Physicians, Philadelphia, and Villanova University, Villanova, Pennsylvania (J.Y.); Penn Medicine, Philadelphia, Pennsylvania (M.A.F.); University of Massachusetts Medical School/ Saint Vincent Hospital, Worcester, Massachusetts (G.M.A.); Penn Medicine Radnor, Radnor, Pennsylvania (M.C.M.); and Portland Veterans Affairs Medical Center and Oregon Health \& Science University, Portland, Oregon (A.J.O., L.L.H.).

Note: The practice points are meant to guide care based on the best available evidence and may not apply to all patients or individual clinical situations. They should not be used as a replacement for a clinician's judgment. Any reference to a product or process contained in a practice point is not intended as an endorsement of any specific commercial product. All practice points are considered automatically withdrawn or invalid 5 years after publication or once an update has been issued.

Financial Support: Financial support for the development of the practice points comes exclusively from the ACP operating budget.

Disclosures: Disclosures can be viewed at www.acponline.org/ authors/icmje/ConflictOfInterestForms.do?msNum=M21-3272. All financial and intellectual disclosures of interest were declared, and potential conflicts were discussed and managed. Dr. Jokela participated in discussion of the practice points but was recused from authorship and voting due to a moderatelevel conflict of interest (authored recent relevant publications). Dr. Marcucci participated in the discussion of the practice points but was recused from authorship and voting due to a moderate-level conflict of interest (author of relevant systematic review). A record of disclosures of interest and management of conflicts is kept for each SMPC meeting and conference call and can be viewed at www.acponline.org/about-acp/who-weare/leadership/boards-committees-councils/scientific-medicalpolicy-committee/disclosure-of-interests-and-conflict-of-interestmanagement-summary-for-scientific-medical-policy.

Corresponding Author: Amir Qaseem, MD, PhD, MHA, American College of Physicians, 190 N. Independence Mall West, Philadelphia, PA 19106; e-mail, aqaseem@acponline.org.

Author contributions are available at Annals.org.

\section{References}

1. Advisory Committee on Immunization Practices. COVID-19 ACIP Vaccine Recommendations. Accessed at www.cdc.gov/vaccines/ hcp/acip-recs/vacc-specific/covid-19.html on 1 December 2021.

2. World Health Organization. COVID-19 advice for the public: Getting vaccinated. Accessed at www.who.int/emergencies/diseases/novelcoronavirus-2019/covid-19-vaccines/advice on 1 December 2021.

3. Arkhipova-Jenkins I, Helfand M, Armstrong C, et al. Antibody response after SARS-CoV-2 infection and implications for immunity: a rapid living review. Ann Intern Med. 2021;174:811-21. [PMID: 33721517] doi:10.7326/M20-7547
4. Qaseem A, Yost J, Etxeandia-lkobaltzeta I, et al; Scientific Medical Policy Committee of the American College of Physicians. What is the antibody response and role in conferring natural immunity after SARS-CoV-2 infection? Rapid, living practice points from the American College of Physicians (version 1). Ann Intern Med. 2021;174:828-35. [PMID: 33721518] doi:10.7326/M20-7569

5. Helfand M, Fiordalisi C, Wiedrick J, et al. Risk of reinfection after SARS-CoV-2. Living rapid review for ACP practice points on the role of the antibody response in conferring immunity following SARSCoV-2 infection. Ann Intern Med. 25 January 2022. [Epub ahead of print]. doi:10.7326/M21-4245

6. Helfand M, Fiordalisi C, Wiedrick J, et al. Risk of Reinfection From SARS-CoV-2 - An Update of an Antibody Response Following SARS-CoV-2 Infection and Implications for Immunity: A Living Rapid Review. (Prepared by the Scientific Resource Center under contract no. 290-2017-0003.) AHRQ publication no. 21-EHC034. Agency for Healthcare Research and Quality; January 2022. Posted final reports are located on the Effective Health Care Program search page. doi:10. 23970/AHRQEPCCOVIDIMMUNITY2

7. Qaseem A, Yost J, Forciea MA, et al; Scientific Medical Policy Committee of the American College of Physicians. The development of living, rapid practice points: summary of methods from the Scientific Medical Policy Committee of the American College of Physicians. Ann Intern Med. 2021;174:1126-32. [PMID: 34029483] doi:10.7326/M20-7641

8. Abo-Leyah H, Gallant S, Cassidy D, et al. The protective effect of SARS-CoV-2 antibodies in Scottish healthcare workers. ERJ Open Res. 2021;7. [PMID: 34104643] doi:10.1183/23120541.00080-2021 9. Abu-Raddad LJ, Chemaitelly H, Coyle P, et al. SARS-CoV-2 antibody-positivity protects against reinfection for at least seven months with 95\% efficacy. EClinicalMedicine. 2021;35:100861. [PMID: 33937733] doi:10.1016/j.eclinm.2021.100861

10. Finch $E$, Lowe R, Fischinger $S$, et al. SARS-CoV-2 infection and reinfection in a seroepidemiological workplace cohort in the United States. medRxiv. Preprint posted online 6 May 2021. doi:10.1101/ 2021.05.04.21256609

11. Gallais F, Gantner P, Bruel T, et al. Anti-SARS-CoV-2 antibodies persist for up to 13 months and reduce risk of reinfection. medRxiv. Preprint posted online 17 May 2021. doi:10.1101/2021.05.07.21256823 12. Goldberg $Y$, Mandel M, Woodbridge $Y$, et al. Protection of previous SARS-CoV-2 infection is similar to that of BNT162b2 vaccine protection: a three-month nationwide experience from Israel. medRxiv. Preprint posted online 24 April 2021. doi:10.1101/ 2021.04.20.21255670

13. Hall VJ, Foulkes S, Charlett A, et al; SIREN Study Group. SARSCoV-2 infection rates of antibody-positive compared with antibodynegative health-care workers in England: a large, multicentre, prospective cohort study (SIREN). Lancet. 2021;397:1459-69. [PMID: 33844963] doi:10.1016/S0140-6736(21)00675-9

14. Hanrath AT, Payne BAI, Duncan CJA. Prior SARS-CoV-2 infection is associated with protection against symptomatic reinfection [Letter]. J Infect. 2021;82:e29-e30. [PMID: 33373652] doi:10.1016/ j.jinf.2020.12.023

15. Hansen CH, Michlmayr D, Gubbels SM, et al. Assessment of protection against reinfection with SARS-CoV-2 among 4 million PCR-tested individuals in Denmark in 2020: a population-level observational study. Lancet. 2021;397:1204-12. [PMID: 33743221] doi:10.1016/S0140-6736(21)00575-4

16. Harvey RA, Rassen JA, Kabelac CA, et al. Association of SARS-CoV2 seropositive antibody test with risk of future infection. JAMA Intern Med. 2021;181:672-9. [PMID: 33625463] doi:10.1001/jamainternmed. 2021.0366

17. Jeffery-Smith A, lyanger N, Williams SV, et al. Antibodies to SARS-CoV-2 protect against re-infection during outbreaks in care homes, September and October 2020. Euro Surveill. 2021;26. [PMID: 33541486] doi:10.2807/1560-7917.ES.2021.26.5.2100092 
18. Krutikov M, Palmer T, Tut G, et al. Incidence of SARS-CoV-2 infection according to baseline antibody status in staff and residents of 100 long term care facilities (VIVALDI study). medRxiv. Preprint posted online 10 March 2021. doi:10.1101/2021.03.08.21253110

19. Leidi A, Koegler F, Dumont R, et al; SEROCoV-POP study group. Risk of reinfection after seroconversion to SARS-CoV-2: a population-based propensity-score matched cohort study. Clin Infect Dis. 2021. [PMID: 34043763] doi:10.1093/cid/ciab495

20. Lumley SF, O'Donnell D, Stoesser NE, et al; Oxford University Hospitals Staff Testing Group. Antibody status and incidence of SARS-CoV-2 infection in health care workers. N Engl J Med. 2021; 384:533-40. [PMID: 33369366] doi:10.1056/NEJMoa2034545

21. Manica M, Pancheri S, Poletti $P$, et al. The risk of symptomatic reinfection during the second COVID-19 wave in individuals previously exposed to SARS-CoV-2. medRxiv. Preprint posted online 20 April 2021. doi:10.1101/2021.04.14.21255502

22. Pilz S, Chakeri A, loannidis JP, et al. SARS-CoV-2 re-infection risk in Austria. Eur J Clin Invest. 2021;51:e13520. [PMID: 33583018] doi:10.1111/eci.13520

23. Rennert L, McMahan C. Risk of SARS-CoV-2 reinfection in a university student population. Clin Infect Dis. 2021. [PMID: 33993225] doi:10.1093/cid/ciab454

24. Sheehan MM, Reddy AJ, Rothberg MB. Reinfection rates among patients who previously tested positive for coronavirus disease 2019: a retrospective cohort study. Clin Infect Dis. 2021;73:1882-6. [PMID: 33718968] doi:10.1093/cid/ciab234

25. Vitale J, Mumoli N, Clerici P, et al. Assessment of SARS-CoV-2 reinfection 1 year after primary infection in a population in Lombardy, Italy [Letter]. JAMA Intern Med. 2021;181:1407-8. [PMID: 34048531] doi:10.1001/jamainternmed.2021.2959

26. Andrey DO, Cohen P, Meyer B, et al. Head-to-head accuracy comparison of three commercial COVID-19 $\mathrm{lgM} / \mathrm{lgG}$ serology rapid tests. J Clin Med. 2020;9. [PMID: 32722191] doi:10.3390/jcm9082369

27. Andrey DO, Cohen P, Meyer B, et al; Geneva Centre for Emerging Viral Diseases. Diagnostic accuracy of Augurix COVID-19 IgG serology rapid test. Eur J Clin Invest. 2020;50:e13357. [PMID: 32691863] doi:10.1111/eci.13357

28. Bao Y, Ling Y, Chen YY, et al. Dynamic anti-spike protein antibody profiles in COVID-19 patients. Int J Infect Dis. 2021;103:5408. [PMID: 33310028] doi:10.1016/j.ijid.2020.12.014

29. Blain $\mathrm{H}$, Rolland $Y$, Tuaillon $E$, et al. Efficacy of a test-retest strategy in residents and health care personnel of a nursing home facing a COVID-19 outbreak. J Am Med Dir Assoc. 2020;21:933-6. [PMID: 32674822] doi:10.1016/j.jamda.2020.06.013

30. Bruni M, Cecatiello V, Diaz-Basabe A, et al. Persistence of antiSARS-CoV-2 antibodies in non-hospitalized COVID-19 convalescent health care workers. J Clin Med. 2020;9. [PMID: 33019628] doi:10. 3390/jcm9103188

31. Chen $Y, K e Y$, Liu $X$, et al. Clinical features and antibody response of patients from a COVID-19 treatment hospital in Wuhan, China. J Med Virol. 2021;93:2782-9. [PMID: 33085103] doi:10.1002/jmv.26617

32. Chen Y, Zuiani A, Fischinger S, et al. Quick COVID-19 healers sustain anti-SARS-CoV-2 antibody production. Cell. 2020;183:14961507.e16. [PMID: 33171099] doi:10.1016/j.cell.2020.10.051

33. Chirathaworn $C$, Sripramote $M$, Chalongviriyalert $P$, et al. SARSCoV-2 RNA shedding in recovered COVID-19 cases and the presence of antibodies against SARS-CoV-2 in recovered COVID-19 cases and close contacts, Thailand, April-June 2020. PLoS One. 2020;15: e0236905. [PMID: 33119712] doi:10.1371/journal.pone.0236905

34. Choe JY, Kim JW, Kwon HH, et al. Diagnostic performance of immunochromatography assay for rapid detection of IgM and IgG in coronavirus disease 2019. J Med Virol. 2020;92:2567-72. [PMID: 32458479] doi:10.1002/jmv.26060

35. Crawford KHD, Dingens AS, Eguia R, et al. Dynamics of neutralizing antibody titers in the months after severe acute respiratory syndrome coronavirus 2 infection. J Infect Dis. 2021;223:197-205. [PMID: 33535236] doi:10.1093/infdis/jiaa618
36. Dave M, Poswal L, Bedi V, et al. Study of antibody-based rapid card test in COVID-19 patients admitted in a tertiary care COVID hospital in Southern Rajasthan. Journal, Indian Academy of Clinical Medicine. 2020;21:7-11.

37. de la Iglesia J, Fernández-Villa T, Fegeneda-Grandes JM, et al. Concordance between two rapid diagnostic tests for the detection of antibodies against SARS-CoV-2. Semergen. 2020;46 Suppl 1:2125. [PMID: 32675000] doi:10.1016/j.semerg.2020.06.009

38. Dellière $S$, Salmona $M$, Minier $M$, et al; Saint-Louis CORE (COvid REsearch) group. Evaluation of the COVID-19 IgG/lgM rapid test from Orient Gene Biotech. J Clin Microbiol. 2020;58. [PMID: 32518071] doi:10.1128/JCM.01233-20

39. Fafi-Kremer S, Bruel T, Madec Y, et al. Serologic responses to SARS-CoV-2 infection among hospital staff with mild disease in eastern France. EBioMedicine. 2020;59:102915. [PMID: 32747185] doi:10.1016/j.ebiom.2020.102915

40. Flannery DD, Gouma S, Dhudasia MB, et al. SARS-CoV-2 seroprevalence among parturient women in Philadelphia. Sci Immunol. 2020;5. [PMID: 32727884] doi:10.1126/sciimmunol.abd5709

41. Gudbjartsson DF, Norddahl GL, Melsted P, et al. Humoral immune response to SARS-CoV-2 in Iceland. N Engl J Med. 2020;383:1724-34. [PMID: 32871063] doi:10.1056/NEJMoa2026116

42. Hou H, Wang T, Zhang B, et al. Detection of IgM and IgG antibodies in patients with coronavirus disease 2019. Clin Transl Immunology. 2020;9:e01136. [PMID: 32382418] doi:10.1002/cti2.1136

43. Huang $M$, Lu QB, Zhao $H$, et al. Temporal antibody responses to SARS-CoV-2 in patients of coronavirus disease 2019 [Letter]. Cell Discov. 2020;6:64. [PMID: 32983570] doi:10.1038/s41421-02000209-2

44. Imai K, Tabata S, Ikeda M, et al. Clinical evaluation of an immunochromatographic lgM/lgG antibody assay and chest computed tomography for the diagnosis of COVID-19. J Clin Virol. 2020;128: 104393. [PMID: 32387968] doi:10.1016/j.jcv.2020.104393

45. Infantino M, Grossi V, Lari B, et al. Diagnostic accuracy of an automated chemiluminescent immunoassay for anti-SARS-CoV-2 IgM and IgG antibodies: an Italian experience. J Med Virol. 2020; 92:1671-5. [PMID: 32330291] doi:10.1002/jmv.25932

46. Isho $B$, Abe KT, Zuo $M$, et al. Persistence of serum and saliva antibody responses to SARS-CoV-2 spike antigens in COVID-19 patients. Sci Immunol. 2020;5. [PMID: 33033173] doi:10.1126/ sciimmunol.abe5511

47. Iversen K, Bundgaard H, Hasselbalch RB, et al. Risk of COVID-19 in health-care workers in Denmark: an observational cohort study. Lancet Infect Dis. 2020;20:1401-8. [PMID: 32758438] doi:10.1016/ S1473-3099(20)30589-2

48. Iyer AS, Jones FK, Nodoushani A, et al. Persistence and decay of human antibody responses to the receptor binding domain of SARS-CoV-2 spike protein in COVID-19 patients. Sci Immunol. 2020;5. [PMID: 33033172] doi:10.1126/sciimmunol.abe0367

49. Jääskeläinen AJ, Kekäläinen $E$, Kallio-Kokko $H$, et al. Evaluation of commercial and automated SARS-CoV-2 IgG and IgA ELISAs using coronavirus disease (COVID-19) patient samples. Euro Surveill. 2020;25. [PMID: 32400364] doi:10.2807/1560-7917.ES. 2020.25.18.2000603

50. Ko JH, Joo EJ, Park SJ, et al. Neutralizing antibody production in asymptomatic and mild COVID-19 patients, in comparison with pneumonic COVID-19 patients. J Clin Med. 2020;9. [PMID: 32708872] doi:10.3390/jcm9072268

51. Koblischke M, Traugott MT, Medits I, et al. Dynamics of CD4 T cell and antibody responses in COVID-19 patients with different disease severity. Front Med (Lausanne). 2020;7:592629. [PMID: 33262993] doi:10.3389/fmed.2020.592629

52. Kwon JS, Kim JY, Kim MC, et al. Factors of severity in patients with COVID-19: cytokine/chemokine concentrations, viral load, and antibody responses. Am J Trop Med Hyg. 2020;103:2412-8. [PMID: 33124544] doi:10.4269/ajtmh.20-1110 
53. Li K, Huang B, Wu M, et al. Dynamic changes in anti-SARS-CoV-2 antibodies during SARS-CoV-2 infection and recovery from COVID19. Nat Commun. 2020;11:6044. [PMID: 33247152] doi:10.1038/ s41467-020-19943-y

54. Liu J, Guo J, Xu Q, et al. Detection of IgG antibody during the follow-up in patients with COVID-19 infection [Letter]. Crit Care. 2020;24:448. [PMID: 32690058] doi:10.1186/s13054-020-03138-4

55. Liu J, Lian R, Zhang G, et al. Changes in serum virus-specific lgM/ IgG antibody in asymptomatic and discharged patients with reoccurring positive COVID-19 nucleic acid test (RPNAT). Ann Med. 2021;53:34-42. [PMID: 32808808] doi:10.1080/07853890.2020.1811887

56. Liu L, Liu W, Zheng Y, et al. A preliminary study on serological assay for severe acute respiratory syndrome coronavirus 2 (SARS-CoV-2) in 238 admitted hospital patients. Microbes Infect. 2020;22:206-11. [PMID: 32425648] doi:10.1016/j.micinf.2020.05.008

57. Liu R, Liu X, Yuan L, et al. Analysis of adjunctive serological detection to nucleic acid test for severe acute respiratory syndrome coronavirus 2 (SARS-CoV-2) infection diagnosis. Int Immunopharmacol. 2020;86: 106746. [PMID: 32619956] doi:10.1016/j.intimp.2020.106746

58. Liu X, Wang J, Xu X, et al. Patterns of IgG and IgM antibody response in COVID-19 patients [Letter]. Emerg Microbes Infect. 2020;9:1269-74. [PMID: 32515684] doi:10.1080/22221751.2020.1773324

59. Lynch KL, Whitman JD, Lacanienta NP, et al. Magnitude and kinetics of anti-severe acute respiratory syndrome coronavirus 2 antibody responses and their relationship to disease severity. Clin Infect Dis. 2021;72:301-8. [PMID: 33501951] doi:10.1093/cid/ ciaa979

60. Pancrazzi A, Magliocca P, Lorubbio M, et al. Comparison of serologic and molecular SARS-CoV 2 results in a large cohort in Southern Tuscany demonstrates a role for serologic testing to increase diagnostic sensitivity. Clin Biochem. 2020;84:87-92. [PMID: 32702365] doi:10.1016/j.clinbiochem.2020.07.002

61. Payne DC, Smith-Jeffcoat SE, Nowak G, et al; CDC COVID-19 Surge Laboratory Group. SARS-CoV-2 infections and serologic responses from a sample of U.S. Navy service members-USS Theodore Roosevelt, April 2020. MMWR Morb Mortal Wkly Rep. 2020;69:714-21. [PMID: 32525850] doi:10.15585/mmwr.mm6923e4 62. Petersen LR, Sami S, Vuong N, et al. Lack of antibodies to severe acute respiratory syndrome coronavirus 2 (SARS-CoV-2) in a large cohort of previously infected persons. Clin Infect Dis. 2021;73: e3066-e3073. [PMID: 33147319] doi:10.1093/cid/ciaa1685

63. Qu J, Wu C, Li X, et al. Profile of immunoglobulin G and IgM antibodies against severe acute respiratory syndrome coronavirus 2 (SARS-CoV-2). Clin Infect Dis. 2020;71:2255-8. [PMID: 32337590] doi:10.1093/cid/ciaa489

64. Robbins T, Kyrou I, Laird S, et al. Healthcare staff perceptions and misconceptions regarding antibody testing in the United Kingdom: implications for the next steps for antibody screening. J Hosp Infect. 2021;111:102-6. [PMID: 33309938] doi:10.1016/j. jhin.2020.11.019

65. Schaffner A, Risch L, Weber M, et al. Sustained SARS-CoV-2 nucleocapsid antibody levels in nonsevere COVID-19: a populationbased study [Letter]. Clin Chem Lab Med. 2020;59:e49-e51. [PMID: 33554502] doi:10.1515/cclm-2020-1347

66. Seow J, Graham C, Merrick B, et al. Longitudinal observation and decline of neutralizing antibody responses in the three months following SARS-CoV-2 infection in humans. Nat Microbiol. 2020;5:1598-607. [PMID: 33106674] doi:10.1038/s41564-020-00813-8

67. Shang Y, Liu T, Li J, et al. Factors affecting antibody response to SARS-CoV-2 in patients with severe COVID-19 [Letter]. J Med Virol. 2021;93:612-4. [PMID: 33289107] doi:10.1002/jmv.26379

68. Shen B, Zheng Y, Zhang $X$, et al. Clinical evaluation of a rapid colloidal gold immunochromatography assay for SARS-Cov-2 lgM/ IgG. Am J Transl Res. 2020;12:1348-54. [PMID: 32355546]

69. Shu H, Wang S, Ruan S, et al. Dynamic changes of antibodies to SARS-CoV-2 in COVID-19 patients at early stage of outbreak. Virol
Sin. 2020;35:744-51. [PMID: 32720214] doi:10.1007/s12250-02000268-5

70. Staines HM, Kirwan DE, Clark DJ, et al. IgG seroconversion and pathophysiology in severe acute respiratory syndrome coronavirus 2 infection. Emerg Infect Dis. 2021;27. [PMID: 33256890] doi:10.3201/eid2701.203074

71. Stock da Cunha T, Gomá-Garcés E, Avello A, et al. The spectrum of clinical and serological features of COVID-19 in urban hemodialysis patients. J Clin Med. 2020;9. [PMID: 32708750] doi:10. 3390/jcm9072264

72. Sun $B$, Feng $Y$, Mo $X$, et al. Kinetics of SARS-CoV-2 specific IgM and IgG responses in COVID-19 patients. Emerg Microbes Infect. 2020; 9:940-8. [PMID: 32357808] doi:10.1080/22221751.2020.1762515

73. Suthar MS, Zimmerman MG, Kauffman RC, et al. Rapid generation of neutralizing antibody responses in COVID-19 patients. Cell Rep Med. 2020;1:100040. [PMID: 32835303] doi:10.1016/j.xcrm. 2020.100040

74. Takahashi T, Wong P, Ellingson MK, et al; Yale IMPACT research team. Sex differences in immune responses to SARS-CoV-2 that underlie disease outcomes. med. Rxiv. 2020. [PMID: 32577695] doi:10.1101/ 2020.06.06.20123414

75. Terpos E, Politou M, Sergentanis TN, et al. Anti-SARS-CoV-2 antibody responses in convalescent plasma donors are increased in hospitalized patients; subanalyses of a phase 2 clinical study. Microorganisms. 2020;8. [PMID: 33260775] doi:10.3390/microorganisms8121885

76. Theel ES, Harring J, Hilgart $\mathrm{H}$, et al. Performance characteristics of four high-throughput immunoassays for detection of IgG antibodies against SARS-CoV-2. J Clin Microbiol. 2020;58. [PMID: 32513859] doi:10.1128/JCM.01243-20

77. Traugott M, Aberle SW, Aberle JH, et al. Performance of severe acute respiratory syndrome coronavirus 2 antibody assays in different stages of infection: comparison of commercial enzyme-linked immunosorbent assays and rapid tests. J Infect Dis. 2020;222:3626. [PMID: 32473021] doi:10.1093/infdis/jiaa305

78. Van Elslande J, Decru B, Jonckheere S, et al. Antibody response against SARS-CoV-2 spike protein and nucleoprotein evaluated by four automated immunoassays and three ELISAs. Clin Microbiol Infect. 2020;26:1557.e1-1557.e7. [PMID: 32745595] doi:10.1016/j.cmi.2020.07.038

79. Wang B, Van Oekelen O, Mouhieddine TH, et al. A tertiary center experience of multiple myeloma patients with COVID-19: lessons learned and the path forward. medRxiv. Preprint posted online 29 June 2020. doi:10.1101/2020.06.04.20122846

80. Wang K, Long QX, Deng HJ, et al. Longitudinal dynamics of the neutralizing antibody response to severe acute respiratory syndrome coronavirus 2 (SARS-CoV-2) infection. Clin Infect Dis. 2021;73:e531-e539. [PMID: 32745196] doi:10.1093/cid/ciaa1143

81. Wang P. Combination of serological total antibody and RT-PCR test for detection of SARS-COV-2 infections. J Virol Methods. 2020;283:113919. [PMID: 32554043] doi:10.1016/j.jviromet.2020.113919

82. Wendel S, Kutner JM, Fontao-Wendel R, et al. Screening for SARS-CoV-2 antibodies in convalescent plasma (CCP) in Brazil: results from a voluntary convalescent donor program. Transfusion. 2020;60:296A.

83. Wolff F, Dahma H, Duterme C, et al. Monitoring antibody response following SARS-CoV-2 infection: diagnostic efficiency of 4 automated immunoassays. Diagn Microbiol Infect Dis. 2020;98:115140. [PMID: 32829098] doi:10.1016/j.diagmicrobio.2020.115140

84. Xiang F, Wang X, He X, et al. Antibody detection and dynamic characteristics in patients with coronavirus disease 2019. Clin Infect Dis. 2020;71:1930-4. [PMID: 32306047] doi:10.1093/cid/ciaa461

85. Xie L, Wu Q, Lin $\mathrm{Q}$, et al. Dysfunction of adaptive immunity is related to severity of COVID-19: a retrospective study. Ther Adv Respir Dis. 2020;14:1753466620942129. [PMID: 32684101] doi:10.1177/ 1753466620942129

Annals of Internal Medicine 
86. Xu X, Sun J, Nie S, et al. Seroprevalence of immunoglobulin M and G antibodies against SARS-CoV-2 in China. Nat Med. 2020;26:1193-5. [PMID: 32504052] doi:10.1038/s41591-020-0949-6

87. Young BE, Ong SWX, Ng LFP, et al; Singapore 2019 Novel Coronavirus Outbreak Research Team. Viral dynamics and immune correlates of coronavirus disease 2019 (COVID-19) severity. Clin Infect Dis. 2021;73:e2932-e2942. [PMID: 32856707] doi:10.1093/ $\mathrm{cid} / \mathrm{ciaa} 1280$

88. Zhang B, Zhou X, Zhu C, et al. Immune phenotyping based on the neutrophil-to-lymphocyte ratio and IgG level predicts disease severity and outcome for patients with COVID-19. Front Mol Biosci. 2020;7:157. [PMID: 32719810] doi:10.3389/fmolb.2020.00157

89. Zhao G, Su Y, Sun $X$, et al. A comparative study of the laboratory features of COVID-19 and other viral pneumonias in the recovery stage. J Clin Lab Anal. 2020;34:e23483. [PMID: 32696465] doi:10.1002/jcla.23483

90. Zhao J, Yuan Q, Wang $\mathrm{H}$, et al. Antibody responses to SARSCoV-2 in patients with novel coronavirus disease 2019. Clin Infect Dis. 2020;71:2027-34. [PMID: 32221519] doi:10.1093/cid/ciaa344

91. Zheng Y, Yan M, Wang L, et al. Analysis of the application value of serum antibody detection for staging of COVID-19 infection. J Med Virol. 2021;93:899-906. [PMID: 32779744] doi:10.1002/jmv. 26330

92. World Health Organization. Advice on the use of masks in the context of COVID-19: interim guidance, 5 June 2020. Accessed at https://apps.who.int/iris/handle/10665/332293 on 1 December 2021.
93. Centers for Disease Control and Prevention. Interim Public Health Recommendations for Fully Vaccinated People. Accessed at www.cdc.gov/coronavirus/2019-ncov/vaccines/fully-vaccinatedguidance.html on 1 December 2021.

94. Centers for Disease Control and Prevention. Using Antibody Tests for COVID-19. Accessed at www.cdc.gov/coronavirus/2019ncov/lab/resources/antibody-tests.html on 1 December 2021.

95. Watson J, Richter A, Deeks J. Testing for SARS-CoV-2 antibodies. BMJ. 2020;370:m3325. [PMID: 32900692] doi:10.1136/bmj. m3325

96. Gazit S, Shlezinger R, Perez G, et al. Comparing SARS-CoV-2 natural immunity to vaccine-induced immunity: reinfections versus breakthrough infections. medRxiv. Preprint posted online 25 August 2021. doi:10.1101/2021.08.24.21262415

97. Cavanaugh AM, Spicer KB, Thoroughman D, et al. Reduced risk of reinfection with SARS-CoV-2 after COVID-19 vaccination-Kentucky, May-June 2021. MMWR Morb Mortal Wkly Rep. 2021;70:1081-3. [PMID: 34383732] doi:10.15585/mmwr.mm7032e1

98. Hagan LM, McCormick DW, Lee C, et al. Outbreak of SARS-CoV2 B.1.617.2 (Delta) variant infections among incarcerated persons in a federal prison-Texas, July-August 2021. MMWR Morb Mortal Wkly Rep. 2021;70:1349-54. [PMID: 34555009] doi:10.15585/ mmwr.mm7038e3

99. Centers for Disease Control and Prevention. How to Protect Yourself \& Others. Accessed at www.cdc.gov/coronavirus/2019ncov/prevent-getting-sick/prevention.html on 1 December 2021. 
Author Contributions: Conception and design: M.A. Forciea, A. J. Obley, A. Qaseem, J. Yost.

Analysis and interpretation of the data: E.A. Akl, A. Dunn, I. Etxeandia-lkobaltzeta, M.A. Forciea, L.L. Humphrey, D.L. Kansagara, M.C. Miller, A.J. Obley, A. Qaseem, M.P. Tschanz, J. Yost.

Drafting of the article: G.M. Abraham, I. Etxeandia-lkobaltzeta, M.A. Forciea, A.J. Obley, A. Qaseem, J. Yost.

Critical revision for important intellectual content: G.M. Abraham, E.A. Akl, R. Andrews, A. Dunn, I. EtxeandiaIkobaltzeta, M.A. Forciea, R. Haeme, L.L. Humphrey, D.L.
Kansagara, M.C. Miller, A.J. Obley, A. Qaseem, M.P. Tschanz, J. Yost.

Final approval of the article: G.M. Abraham, E.A. Akl, R. Andrews, A. Dunn, I. Etxeandia-lkobaltzeta, M.A. Forciea, R. Haeme, L.L. Humphrey, D.L. Kansagara, M.C. Miller, A.J. Obley, A. Qaseem, M.P. Tschanz, J. Yost.

Statistical expertise: A. Qaseem, J. Yost.

Administrative, technical, or logistic support: I. EtxeandiaIkobaltzeta, A. Qaseem, J. Yost.

Collection and assembly of data: A.J. Obley, J. Yost.

\begin{tabular}{|c|c|c|}
\hline Key Question & Version 1 & Version 2* \\
\hline KQ 1 & $\begin{array}{l}\text { What are the prevalence, level, and durability of detectable anti- } \\
\text { SARS-CoV-2 antibodies among patients infected with or recov- } \\
\text { ered from reverse transcriptase polymerase chain reaction } \\
\text { (RT-PCR)-diagnosed SARS-CoV-2 infection? }\end{array}$ & $\begin{array}{l}\text { What are the prevalence, level, and duration of detectable anti-SARS- } \\
\text { CoV-2 antibodies among patients infected with or recovered from } \\
\text { reverse transcriptase polymerase chain reaction (RT-PCR)-diagnosed } \\
\text { SARS-CoV- } 2 \text { infection? }\end{array}$ \\
\hline KQ 1a & $\begin{array}{l}\text { Do the levels and durability of detectable antibodies vary by } \\
\text { patient characteristics (for example, age, sex, race/ethnicity, } \\
\text { and comorbidities), COVID-19 severity, presence of symp- } \\
\text { toms, time from symptom onset, or the characteristics of the } \\
\text { immunoassay (sensitivity or specificity)? }\end{array}$ & $\begin{array}{l}\text { Do the levels and durability of detectable antibodies vary by patient } \\
\text { characteristics (for example, age, sex, race/ethnicity, and comor- } \\
\text { bidities), COVID-19 severity (severity of the initial infection), } \\
\text { presence of symptoms, time from symptom onset, or the charac- } \\
\text { teristics of the immunoassay (sensitivity, specificity)? }\end{array}$ \\
\hline KO 2 & $\begin{array}{l}\text { Do anti-SARS-CoV-2 antibodies confer natural immunity against } \\
\text { reinfection? }\end{array}$ & $\begin{array}{l}\text { What is the risk for reinfection with SARS-CoV-2 among adults with } \\
\text { prior SARS-CoV-2 infection? } \\
\text { Revised to include studies in which infection (cohort allocation) was } \\
\text { documented by PCR (or by a combination of PCR and antibody } \\
\text { testing) rather than by seroconversion or presumed seroconver- } \\
\text { sion only, as well as to address magnitude of protection against } \\
\text { future reinfection }\end{array}$ \\
\hline $\mathrm{KQ} 2 \mathrm{~b}$ & $\begin{array}{l}\text { Is there a threshold level of detectable anti-SARS-CoV-2 antibod- } \\
\text { ies necessary to confer natural immunity, and if so, does this } \\
\text { threshold vary by patient characteristics (for example, age, } \\
\text { sex, race/ethnicity, and comorbidities)? }\end{array}$ & No changes \\
\hline KO 3 & $\begin{array}{l}\text { If anti-SARS-CoV-2 antibodies confer natural immunity against } \\
\text { reinfection, how long does this immunity last? }\end{array}$ & $\begin{array}{l}\text { What is the duration of protection against reinfection among } \\
\text { adults with prior SARS-CoV-2 infection? } \\
\text { Revised to include studies in which infection (cohort allocation) was } \\
\text { documented by PCR (or by a combination of PCR and antibody } \\
\text { testing) rather than by seroconversion or presumed seroconver- } \\
\text { sion only }\end{array}$ \\
\hline KO 4 & $\begin{array}{l}\text { What are the unintended consequences of antibody testing after } \\
\text { SARS-CoV-2 infection? }\end{array}$ & No changes \\
\hline
\end{tabular}

$\mathrm{KQ}=$ key question; $\mathrm{PCR}=$ polymerase chain reaction; $\mathrm{RT}-\mathrm{PCR}=$ reverse transcriptase polymerase chain reaction.

* Language modifications are in boldface. 